\title{
Kinetic Approach of Iodine Quantification in Dietary Salts
}

\author{
Gildas K. Gbassi ${ }^{1,2}{ }^{*}$, Thodhekes N. S. J. Yao², Patrick G. Atheba ${ }^{3}$, Mariette D. Yehe ${ }^{1,2}$, \\ Germain A. Brou ${ }^{2}$, Michele Ake², Albert Trokourey ${ }^{3}$ \\ ${ }^{1}$ Service Contrôle des Aliments, Eaux et Boissons, Laboratoire National de la Santé Publique (LNSP), Abidjan, \\ Côte d'Ivoire \\ ${ }^{2}$ Département de Chimie Analytique, Chimie Générale et Minérale, UFR Sciences Pharmaceutiques et Biologiques, \\ Université Félix Houphouët Boigny, Abidjan, Cote d'Ivoire \\ ${ }^{3}$ Laboratoire de Chimie Physique, UFR SSMT, Université Félix Houphouët Boigny, Abidjan, Cote d'Ivoire \\ Email: *gildas.gbassi@univ-fhb.edu.ci
}

How to cite this paper: Gbassi, G.K., Yao, T.N.S.J., Atheba, P.G., Yehe, M.D., Brou, G.A., Ake, M. and Trokourey, A. (2017) Kinetic Approach of Iodine Quantification in Dietary Salts. Open Journal of Physical Chemistry, 7, 27-34.

https://doi.org/10.4236/ojpc.2017.72003

Received: February 16, 2017

Accepted: May 8, 2017

Published: May 11, 2017

Copyright $\odot 2017$ by authors and Scientific Research Publishing Inc. This work is licensed under the Creative Commons Attribution International License (CC BY 4.0).

http://creativecommons.org/licenses/by/4.0/

\begin{abstract}
Iodization of dietary salt is recommended to prevent and control iodine deficiency disorders. The kinetic study of dietary iodized salt proves to be of interest not only for the determination of the conditions of production of iodine, but also for a good knowledge of the kinetic and thermodynamic parameters of the reaction. In this work, two salt brands were studied and one of them was used for the kinetic study. The kinetic study showed that the reaction proceeded slowly at a medium rate. Since the reaction admits a global order equal to 1 , potassium iodide has no influence on this reaction rate. The concentration of iodate ions introduced in the dietary salt is a kinetic parameter that affects the reaction rate. Calculated rate constant was inversely proportional to time. The study has therefore determined experimentally kinetic parameters of the reaction between iodate and iodide ions.
\end{abstract}

\section{Keywords}

Dietary Iodized Salt, Reaction Rate, Reaction Order, Rate Constant

\section{Introduction}

Most of foods with the exception of those from the marine environment are devoid of significant amounts of iodine. Salts, including sea salt contain iodine naturally to trace [1]. Lack of iodine causes various abnormalities qualified as "disorders due to iodine deficiency" (endemic goiter, hypothyroidism, cretinism, lack of reproductive function, anemia, spontaneous abortions and infant mortality) [2] [3] [4] [5] [6]. The iodization of edible salt (salt with iodine fortification) 
is recommended by WHO to prevent iodine deficiency disorders [7]. Salt is used in many households as a source of iodine as well as an effective way to distribute iodine to the population [8]. Salt is the ideal vehicle for iodine because it is an essential nutrient [2]. Iodine is an essential substrate for the body and for the synthesis of thyroid hormone [9] [10]. It is used in pharmaceutical and chemical industries. Aqueous solutions of di-iodine used in various assays are generally obtained in acid medium between iodate and excess of iodide. Iodine is found mainly in anionic form (iodide and iodate). Depending on the state of saturation in the soil, either species predominates [11] [12] [13]. Aerobically is iodate which is predominantly present in the soil solution [14]. The reaction between iodate and iodide is important because it allows the extraction of iodine from the liquid effluent for its industrial preparation. However, iodine is an unstable product which sublime slowly at room temperature. A hot and humid climate is afactor contributing to the impoverishment of food iodized salts [15].

Many studies on the determination of iodine in salt exist [2] [8], but none has studied the kinetic approach of iodine quantification. Given these observations, this work aims to follow the kinetic of iodine quantification in dietary salts. Various kinetic parameters such as reaction rate, reaction order and rate constant were determined.

\section{Materials and Methods}

\subsection{Sampling}

Samples of iodized salt were chosen from two distinct trademarks, a selection has beenmade on the basis of their high selling frequency. These salts were Sali$\mathrm{na}^{\varpi}$ and Enase $^{\oplus}$, respectively in the form of unit packet of $907 \mathrm{~g}$ and $1000 \mathrm{~g}$. The packaging indicated 90 ppm iodine for Salina ${ }^{\circledR}$ and 50.55 to 84.25 ppm iodine for Enasel $^{\oplus}$. Different batches of each brand were used for analysis.

\subsection{Reagents}

The reagents used were of analytical grade and were purchased from various suppliers. Sulfuric acid for analysis (Normapur ${ }^{\circledR}, \mathrm{d}=1.83$, purity $=95 \%$ ); potassium iodide $\left(\right.$ Sharlau $\left.^{\circledR}\right)$, soluble starch $\left(\right.$ Merck $\left.^{\circledR}\right)$, sodium thiosulfate pentahydrate $\left(\right.$ Normapur $\left.{ }^{\circledR}\right)$ and distilled water. Working solutions consist of $1 \mathrm{M}$ sulfuric acid, $1 \%(\mathrm{w} / \mathrm{v})$ soluble starch, $10 \%(\mathrm{w} / \mathrm{v})$ potassium iodide and $2.5 \mathrm{mM}$ sodium thiosulfatepentahydrate. The last two solutions were stored in brown bottles.

\subsection{Iodine Quantification and Kinetic Parameters Determination}

Iodine was measured by titrimetry and required a magnetic stirrer (Fisher brand); a precision balance (Denver Instrument, 0.0001) and a stopwatch (Casio). The experimental device was a traditional burette which consists of glass tube of constant bore with a graduation scale etched on it and a stopcock at the bottom. 
Iodine content of the two types of salt was determined. The mark containing a high amount of iodine was used for the kinetic study. The determination of the reaction rate was assessed by the progress of the reaction over time requires. The time taken to perform the assays was determined, which was carried out by the time which allowed the titration of di-iodine formed. The partial orders of the reaction were calculated according to the assumptions of order 0,1 and 2 . The rate constant was calculated from the knowledge of the reaction rate and the partial orders. Three tests were performed for the determinations of iodine content while five (5) were necessary for the kinetic study.

\subsubsection{Assay Principle}

In the presence of sulfuric acid $\left(\mathrm{H}_{2} \mathrm{SO}_{4}\right)$ and potassium iodide (KI), iodate ion $\left(\mathrm{IO}_{3}^{-}\right)$contained in the salt is reduced. The releaseddi-iodine is analyzed using sodium thiosulfate in the presence of starch as a color indicator. The volume of sodium thiosulfate used is proportional to the amount of di-iodine released by the salt.

The equations of the reaction are as follows:

$$
\begin{gathered}
5 \mathrm{KI}+\mathrm{KIO}_{3}+3 \mathrm{H}_{2} \mathrm{SO}_{4} \rightarrow 3 \mathrm{I}_{2}+\mathrm{H}_{2} \mathrm{O}+3 \mathrm{~K}_{2} \mathrm{SO}_{4} \\
2 \mathrm{Na}_{2} \mathrm{~S}_{2} \mathrm{O}_{3}+\mathrm{I}_{2} \rightarrow \mathrm{Na}_{2} \mathrm{~S}_{4} \mathrm{O}_{6}+2 \mathrm{NaI}
\end{gathered}
$$

\subsubsection{Sampling Preparation}

Prepare $200 \mathrm{~mL}$ of salt solution by dissolving $40 \mathrm{~g}$ of salt in an Erlenmeyer flask of $200 \mathrm{~mL}$. Introduce into a beaker variable volumes of salt solution according to Table 1. Then successively add other reagents in the order listed in Table 1 . The final solution turns yellow, a characteristic of the released di-iodine.

\subsubsection{Released di-Iodine Determination}

Add 2 - 5 drops of starch solution into the beaker, the solution turns to dark purple. Continue stirring and titrate the solution of the beaker with sodium thiosulfate [16]. Start the timer when the first drop of sodium thiosulfate in the beaker falls. Continue the titration until the purple color disappears and the solution becomes colorless. Note the equivalent volume $\left(V_{E}\right)$ and the time $\left(T_{E}\right)$ taken to perform the assay.

Iodine content is given by the Equation (3) as follows:

$$
\text { Iodine }(\mathrm{ppm})=\frac{N \times V \times 21.15 \times 1000}{m}
$$

$N$ : normality of sodium thiosulfate (eq.g. $\left.\cdot \mathrm{L}^{-1}\right)$.

$V$ : volume of sodium thiosulfate (L).

Table 1. Preparation of different samples.

\begin{tabular}{cccccc}
\hline & Beaker 1 & Beaker 2 & Beaker 3 & Beaker 4 & Beaker 5 \\
\hline Salt solution $(\mathrm{mL})$ & 50 & 35 & 25 & 15 & 50 \\
Distilled water $(\mathrm{mL})$ & 0 & 15 & 25 & 35 & 0 \\
$\mathrm{KI} 10 \%(\mathrm{~mL})$ & 5 & 5 & 5 & 5 & 2.5 \\
$\mathrm{H}_{2} \mathrm{SO}_{4} 1 \mathrm{M}(\mathrm{mL})$ & 1 & 1 & 1 & 1 & 1 \\
\hline
\end{tabular}


m: mass of the test portion of dietary salt $(\mathrm{g})$.

21.15 factor: equivalent to $1 / 6$ of the atomic mass of iodine (one mole of iodate reacted with 6 moles of sodium thiosulfate, atomic mass of iodine = 126.9).

ppm $($ part per million $)=1 \mathrm{mg} / \mathrm{Kg}=1 \mu \mathrm{g} / \mathrm{g}$.

\section{Results and Discussion}

\subsection{Iodine Content in Dietary Salts}

Iodine was present in all samples salts. The average content (ppm) was $1.533 \pm$ 0.165 for Salina and $45.374 \pm 0.987$ for Enasel $^{\circ}$. Enase ${ }^{\circledast}$ contains iodine in an amount much higher than Salina ${ }^{\oplus}$. Salina ${ }^{\circledR}$ has iodine content much lower than the value declared by the manufacturer $(90 \mathrm{ppm})$. The World Health Organization (WHO) recommends at least 15 to $20 \mathrm{ppm}$ of iodine in salts. Iodine content in Enase $^{\circledast}$ is less than what is specified on the package (from 50.55 to $84.25 \mathrm{ppm}$ ) but it remains within the recommended standards (WHO). In the work of Adou et al. [2], a minimum level of $0.48 \mathrm{ppm}$ was found in the samples of analyzed salts. Taking into account environmental conditions and in order to provide a sufficient quantity of iodine to each individual, the national program of nutrition in Cote d'Ivoire identified a normal range of 30 - $50 \mathrm{ppm}$ of iodine in households' salts [2]. Mannarand Dunn [17] recommended 30 - 60 ppm of iodine in dietary salts for hot and humid countries. Since all salts on the market are not properly iodized, the prevention of iodine-deficient diseases cannot be avoided. Efforts still need to be made to strengthen the control of marketed salts. For the kinetic study, Enasel ${ }^{\circledR}$ has been chosen, due to its high salt content.

\subsection{Kinetic Parameters Determination}

\subsubsection{Average Rate of Iodate Ions Disappearance}

Monitoring the progress of the reaction over time requires the determination of the reaction rate. The calculation of this rate is presented in Table 2.

The time taken to perform the assays is extended to several seconds, which allowed applying the titration to determine the reaction rate. The formation of di-iodine from iodate and iodide is a slow reaction. The iodate disappearance rate increases when its concentration increases. The concentration is therefore a kinetic factor which has an influence on the rate. This reaction can be profitably exploited to extract iodine from marshes and effluents.

Table 2. Average rate of iodate ions disappearance.

\begin{tabular}{ccccc}
\hline & Beaker 1 & Beaker 2 & Beaker 3 & Beaker 4 \\
\hline $\mathrm{t}(\mathrm{s})$ & 211 & 167 & 100 & 66 \\
{$\left[\mathrm{IO}_{3}^{-}\right]\left(10^{-5} \mathrm{~mol} / \mathrm{L}\right)$} & 25.580 & 17.830 & 10.500 & 7.910 \\
Rate $\left(10^{-6} \mathrm{~mol} \cdot \mathrm{L}^{-1} \cdot \mathrm{s}^{-1}\right)$ & 1.2144 & 1.0679 & 1.050 & 1.194 \\
Average rate & & $(113.14 \pm 8.28) \times 10^{-8} \mathrm{~mol} \cdot \mathrm{L}^{-1} \cdot \mathrm{s}^{-1}$ & \\
\hline
\end{tabular}




\subsubsection{Determination of Reaction Orders}

1) Partial order with respect to iodate ions $\left(\mathrm{IO}_{3}^{-}\right)$

The results of partial order calculations from the assays are shown in Table 3.

The values in Table 3 helped us to draw various curves (Figures 1(a)-(c)).

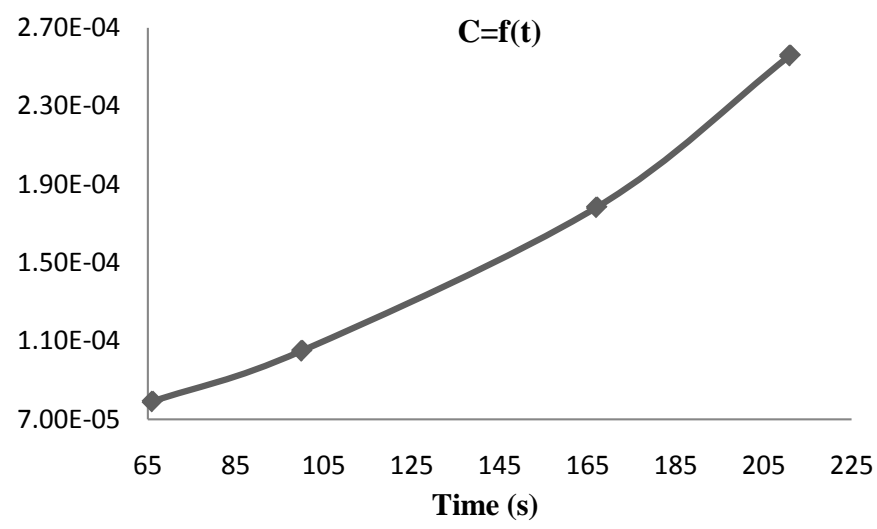

(a)

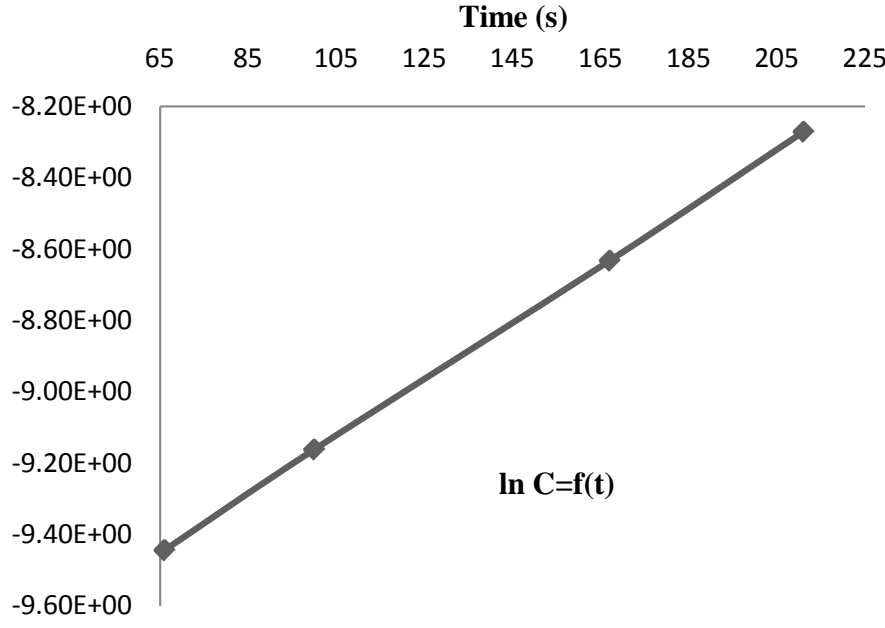

(b)

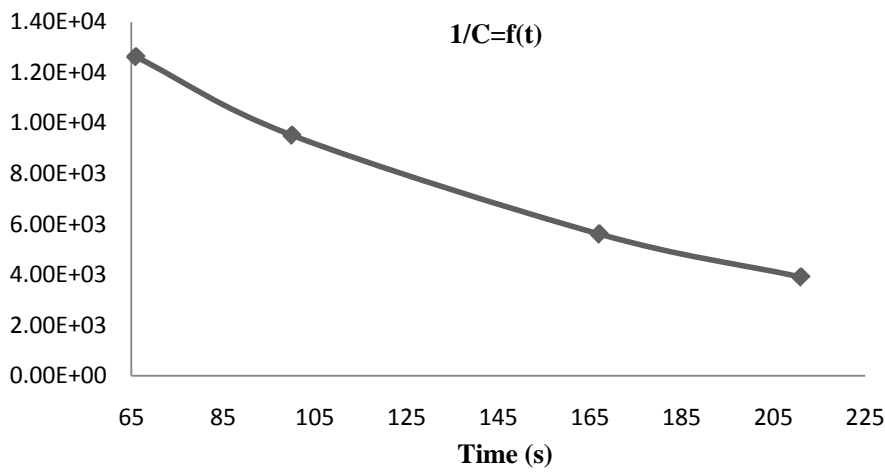

(c)

Figure 1. (a) Graphical representation of iodate concentration as a function of time ( $C=\left[\mathrm{IO}_{3}^{-}\right]$); (b) Graphical representation of the logarithm of iodate concentration as a function of time ( $C=\left[\mathrm{IO}_{3}^{-}\right]$); (c) Graphical representation of the inverse of iodate concentration as a function of time $\left(\mathrm{C}=\left[\mathrm{IO}_{3}^{-}\right]\right)$. 
Table 3. Partial order with respect to $\mathrm{IO}_{3}^{-}$according to the assumptions of order 0,1 and 2 .

\begin{tabular}{ccccc}
\hline & Beaker 1 & Beaker 2 & Beaker 3 & Beaker 4 \\
\hline $\mathrm{t}(\mathrm{s})$ & 211 & 167 & 100 & 66 \\
$\mathrm{C}(\mathrm{mol} / \mathrm{L})$ & 0.0002557 & 0.0001783 & 0.000105 & 0.0000791 \\
$\operatorname{lnC}$ & -8.2713 & -8.6319 & -9.1616 & -9.4440 \\
$1 / \mathrm{C}\left(\mathrm{L} \cdot \mathrm{mol}^{-1}\right)$ & 3910.0684 & 5607.4871 & 9523.8095 & 12631.6853 \\
\hline
\end{tabular}

$C=\left[\mathrm{IO}_{3}^{-}\right]$.

According to the three assumptions of a single order, only a line is obtained when plotting the logarithm of iodate concentration as a function of time. The partial order of reaction with respect to iodate is 1 .

2) Partial order with respect to iodide ions $\left(\mathrm{I}^{-}\right)$

The results of partial order calculations from the assays are shown in Table 4.

The reaction rate with respect to iodide ions $\left(\mathrm{I}^{-}\right)$remains substantially constant despite the variation in iodide concentration. The ratio of the reaction rate expressions of experiments 1 and 5 leads to a partial order equal to 0 after calculation. The partial order of the reaction relative to iodide is therefore 0 . The formation of di-iodine admits a global order equal to 1 . Only the concentration of iodate affects the reaction rate. The order of a reaction is an experimental characteristic that cannot be measured directly.

\subsubsection{Rate Constant Determination}

The rate law is the relation which binds the rate of reaction to the concentrations of all the substances present in the reaction medium, as well as all the factors likely to have an influence on the rate. The general rate law takes into account only reagents.

Knowing the partial orders for each reagent, the expression of the reaction rate was determined as follows:

$$
\begin{gathered}
v=k\left[\mathrm{IO}_{3}^{-}\right]^{1}\left[\mathrm{I}^{-}\right]^{0} \\
v=k\left[\mathrm{IO}_{3}^{-}\right]
\end{gathered}
$$

The average value of the rate constant is $k=(8.14 \pm 3.88) \times 10^{-3} \mathrm{~s}^{-1}$. This value characterizes the inherent rate of the reaction, independently of the influence of concentrations. This rate constant depends only on $\mathrm{IO}_{3}^{-}$. The rate constant of a reaction of order 1 has the dimension of the inverse of time.

\section{Conclusion}

This work was intended to follow the kinetic of iodine quantification in food iodized salts. Iodine content of the two brands of salts allowed us to retain one brand for the kinetic study. Iodine levels show that the salts are not adequately iodized. Some kinetic parameters including average rate, global order of the reaction and rate constant have been assessed. It is apparent that the reaction 
Table 4. Partial order with respect to $\mathrm{I}^{-}$according to the assumptions of order 0,1 and 2.

\begin{tabular}{ccc}
\hline & Beaker 1 & Beaker 5 \\
\hline$\left[\mathrm{IO}_{3}^{-}\right](\mathrm{mol} / \mathrm{L})$ & 0.0002557 & 0.0002541 \\
$\mathrm{t}(\mathrm{s})$ & 211 & 204 \\
Rate $\left(10^{-6} \mathrm{~mol} \cdot \mathrm{L}^{-1} \cdot \mathrm{s}^{-1}\right)$ & 1.21 & 1.24 \\
{$\left[\mathrm{I}^{-}\right](\mathrm{mol} / \mathrm{L})$} & 0.0602 & 0.0301 \\
\hline
\end{tabular}

between iodate and iodide takes place at a slow rate, admits a global order equal to 1 , and the reaction rate is dependent on the concentration of the reactants. This reaction can be used profitably to clean and extract iodine from waste and soil.

\section{Acknowledgements}

The financial support of Felix Houphouet Boigny University has been helpful. The authors would express sincere appreciation to Prof. Malan Kla Anglade for technical comments and manuscript editing.

\section{References}

[1] Valeix, P. (2003) In "L'iode", Dossier Scientifique de l'Institut Français pour la Nutrition, 11-45.

[2] Adou, P., Aka, D. and Ake, M. (2002) Cahiers d'Etudes et de Recherches Francophones Santé, 18-21.

[3] Mannar, V.M.G. (1996) SOS for a Billion, the Conquest of Iodine Deficiency Disorders. In: Hetzel, B.S. and Pandav, C.S., Oxford University Press, New Delhi, 99-118.

[4] Semba, R.D., De Pee, S., Hess, S.Y., Sun, K., Sari, M. and Bloem, M.W. (2008) Child Malnutrition and Mortality among Families Not Utilizing Adequately Iodized Salt in Indonesia. American Journal of Clinical Nutrition, 87, 438-444.

[5] Assoumanou, G.M., Zohoncon, T.M. and Akpona, S.A. (2011) Evaluation de la teneur en iode des sels de cuisine dans les ménages de deux zones d'endémie goitreuse du Bénin. International Journal of Biological and Chemical Sciences, 4 , 1515-1526.

[6] Mamane, N.H., Sadou, H., Alma, M.M. and Daouda, H. (2013) Evaluation de la teneur en iode des sels alimentaires dans la communauté urbaine de Niamey au Niger. Journal de la Societe Ouest Africaine de Chimie, 35, 35-40.

[7] OMS/UNICEF/ICCIDD (1996) Taux recommandés d'iodation du sel et directives pour la surveillance de leur adéquation et efficacité. WHO/NUT/96.13, Genève, 9 p.

[8] Willyard, C. (2008) Salt of the Earth. The Public Health Community Employs a Mineral to Fight Infectious Disease. Geotimes.

http://www.geotimes.org/june08/article.html?id=feature_salt.html

[9] Schlienger, J.L., Goichot, B. and Grunenberger, F. (1997) Iode et fonction thyroïdienne. La Revue de Médecine Interne, 18, 709-716.

[10] Delange, F. (2001) La Thyroïde: Des concepts à la pratique clinique. Elsevier, Paris, 355-362. 
[11] Sheppard, M.I., Thibault, D.H., Mcmurry, J. and Smith, P.A. (1995) Factors Affecting the Soil Sorption of Iodine. Water, Air, and Soil Pollution, 83, 51-67. https://doi.org/10.1007/BF00482593

[12] Yuita, K. (1992) Dynamics of Iodine, Bromine, and Chlorine in Soil. II. Chemical Forms of Iodine in Soil Solutions. Soil Science and Plant Nutrition, 38, 281-287. https://doi.org/10.1080/00380768.1992.10416491

[13] Blazy, P. and Jdid, E-A. (2009) Iode. Techniques de l'Ingénieur. RÉF: J6380 V1.

[14] Behrens, H. (1985) Speciation of Fission and Activation Products in the Environment. In: Bulman, R.A. and Cooper, J.R., Eds., Elsevier Applied Science Publishers, London and New York.

[15] Alaoui, L., Moretti, D. and Zimmermann, M. (2002) Stabilité et acceptabilité du sel enrichi en fer+ iode en zone d'endémie goitreuse. Actes de I Institut Agronomique et Vétérinaire, 1, 5-10.

[16] AOAC (2005) Official method of Analysis. 18th Edition, Association of Officiating Analytical Chemists, Washington DC, Method 935.14 and 992.24.

[17] Mannar, M.G.V. and Dunn, J.T. (1995) Salt Iodization for the Elimination of Iodine Deficiency. ICCID/UNICEF/WHO, International Council for Control of Iodine Deficiency Disorders, The Netherlands.

Submit or recommend next manuscript to SCIRP and we will provide best service for you:

Accepting pre-submission inquiries through Email, Facebook, LinkedIn, Twitter, etc. A wide selection of journals (inclusive of 9 subjects, more than 200 journals) Providing 24-hour high-quality service User-friendly online submission system Fair and swift peer-review system Efficient typesetting and proofreading procedure Display of the result of downloads and visits, as well as the number of cited articles Maximum dissemination of your research work

Submit your manuscript at: http://papersubmission.scirp.org/

Or contact ojpc@scirp.org 